Nevenka Mijatović ${ }^{*}$, Lato Pezo², Anja Terzić1, Snežana Šerbula ${ }^{3}$, Renata Kovačević ${ }^{4}$

${ }^{1}$ University of Belgrade, Institute for Testing of Materials IMS, Belgrade, Serbia, 2 Institute of General and Physical Chemistry, Belgrade, Serbia, ${ }^{3}$ University of Belgrade, Technical Faculty in Bor, Bor, Serbia, ${ }^{4}$ Mining and Metallurgy Institute Bor, Bor, Serbia

Scientific paper

ISSN 0351-9465, E-ISSN 2466-2585

UDC:613.95/.99

doi: $10.5937 /$ ZasMat1801057M

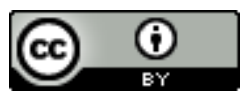

Zastita Materijala 59 (1)

$56-66$ (2018)

\title{
The biometrics techniques for the assessment of the degree of adoption of toxic and essential elements
}

\begin{abstract}
The focus of this study is on the biometric classification of plants, plant organs, sampling sites and sampling time, in terms of toxic ( $\mathrm{As}, \mathrm{Cd}, \mathrm{Hg}$ and $\mathrm{Pb}$ ) and essential elements ( $\mathrm{Cu}$ and $\mathrm{Zn}$ ) monitoring, and possible the application in phyto-remediation. The degree of adoption of elements depends on the plant species and its morphological and physiological properties, therefore the adoption of toxic and essential elements in three plant species (coltsfoot, dandelion and nettles) was investigated. Vegetation experiments were carried out in the coastal region of river Kriveljska, Serbia. Principal component analysis and analysis of variance were used for assessing the effect of plant types, plant organs (root, shoot and leaves), and sampling sites and sampling time (April, May, June) on toxic and essential elements uptake. Obtained results showed that a difference in toxic and essential elements uptake depends mostly upon the cultivar and the plant organ types. Biometric techniques provided a good opportunity for a better understanding the behaviour of plants and obtaining much more useful information from the original data.
\end{abstract}

Keywords: coltsfoot, dandelion, nettles, toxic elements, essential elements, biometrics monitoring.

\section{INTRODUCTION}

The problem of environmental pollution as a result of the industrial-economic and urban development requires an integrated approach to sustainable management and protection of biodiversity. Heavy metals could be characterized as dangerous polluting substances in the environment. Due to bioaccumulation in plants that absorb heavy metals from the soil, heavy metals enter the human food chain and can be deposited in the human organism [1]. There are three categories of heavy metals: toxic metals, precious metals and radionuclides [2]. All three categories of heavy metal are carcinogenic and mutagenic. The high content of pollutants in the environment is reflected in: human and animal health $[3,4]$, erosion of buildings [5], the yield of the plants are reduced, changing the soil structure as well as the pollution of groundwater and surface water [6]. Accumulation of the industrial pollution exerts a very negative impact on ecosystems, especially forests, as well as herbaceous plants [7-10].

\footnotetext{
${ }^{*}$ Corresponding author: Nevenka Mijatović E-mail:milosevic_nevenka@yahoo.com

Paper received: 12. 09. 2017.

Paper accepted: 06. 11. 2017.

Paper is available on the website: www.idk.org.rs/journal
}

According to data from the [11], lead poisoning in children causes neurological damage that causes a reduction in IQ, loss short-term memory, problems in learning and coordinating movement, while arsenic poisoning causes cardiovascular problems, skin cancer and other skin disorders, peripheral neuropathy and kidney damage. Cadmium accumulates in the kidneys, mercury damages the nervous system and causes uncontrollable tremors, muscle damage, partial loss vision and deformities in children.

Biomonitoring is the organized system of monitoring biological changes in time and the space in the best way reflects the complex natural and anthropogenic phenomena, influences and processes, and includes the use of living organisms as bio-indicators [12]. A biological indicator is an organism that can be used for quantification of the relative the level of contamination by measuring the concentration of toxins in tissues. For this purpose can be used the whole body or some part of it [13].

There are three categories of plants that respond differently to the presence of toxic metals, [14]. Some of them adopt heavy metals, retain them in the bud without regardless of their concentration in soil, i.e. fitostabilizators. Another group of plants absorbs and transports heavy metals depending on the contents of heavy metals in the soil, so these plants an assessment of land - 
bioindicators, while the third group of plants accumulates heavy metals in the aboveground parts of plants - bioacumulators. Generally, plants adapted to such land rich in various metals are marked as metalofits and may be indicators of certain minerals, or mineral deposits in different places in the soil [2]. Metalofits store massive amounts of heavy metals (of $0.5 \mathrm{~g} / \mathrm{kg}$, even to 25 $\mathrm{g} / \mathrm{kg}$ dry weight of the plant), approximately in the quantities in which adopted the basic macro, which is 1,000 times more than the amount of necessary microelements [2]. In soil mutually permeate and condition the lithosphere, atmosphere, hydrosphere and biosphere so that together represent one entity, a dynamic system whom circulating matter [14]. The ability of plants to develop resistance to heavy metals in the soil is genetically determined, and in special situations in nature, may be adaptive stimulated. In this case, indicator species can be very suitable for planting and revitalization of the area around the mines and industrial plants or in places where the soil is contaminated with heavy metals [15]. There are numerous literature reports on the effect of heavy metals on a variety of plant species and their authorities. Nettle (Urtica dioica) and dandelion (Taraxacum officinale), due to their proliferation road test plant species around the world, while for large coltsfoot (Petasites officinalis) are not discovered literature data on the use in biomonitoring. Still in 1960, Graupe et al. [17]. study the effect of heavy metals on Dandelion (Taraxacum officinale) for categorizing soil where dandelions grow. The studies by Kabat-Pendias et al. [18], and Królak et al [19] state that the dandelion (Taraxacum officinale) are metals bioindicator of $\mathrm{Cd}, \mathrm{Pb}$ and $\mathrm{Zn}$ content in soil and air. Motowicka-Terelak and Terelak [21], examined dandelion in Poland in function bioindicators sulphur pollution, while Malawska and Wilkomirski [21], also examined Dandelion on heavy metals in Poland and some organic compounds. It is known that nettle in addition to indicating the increased concentration of nitrates and nitrite in the soil, serves as food for the snails to be tested as bioindicators of heavy metal [22-24]. Gaweda and Capecka [25], examined a nettle as the bioindicator of heavy metals for nine years later, while Mousavi in Iran Seyedi [26] use nettle as a bioindicator of nickel and cadmium.

The subject of this paper is to study three types of herb: nettle, dandelion and coltsfoot as bioindicators of environmental pollution in the coastal region of Krivelj River, which is exposed to wastewater for many years. The investigation was performed by the Faculty of Mining, Bor. The aim of this work is that on the basis of results obtained in the heavy metal content soil and plants determines what is the level of pollution in the coastal River Krivelj, as well as to determine the role of species (nettle, dandelion, coltsfoot) in biomonitoring of heavy metals, or whether they act as bioindicators, or bioacumulators fitostabilizators. The aim of this study is to gain a basis for integration and understanding and analyses the connection pollution from all media (water, air, soil) and the tested plant organisms. Also, the idea of research is to promote biometrics techniques for processing experimental data as a method which provides much more useful information for a better understanding the behaviour of plants in comparison to classical methods. Principal Component Analysis (PCA) was applied to the experimental data (used as descriptors) to characterize and differentiate the observed samples [27].

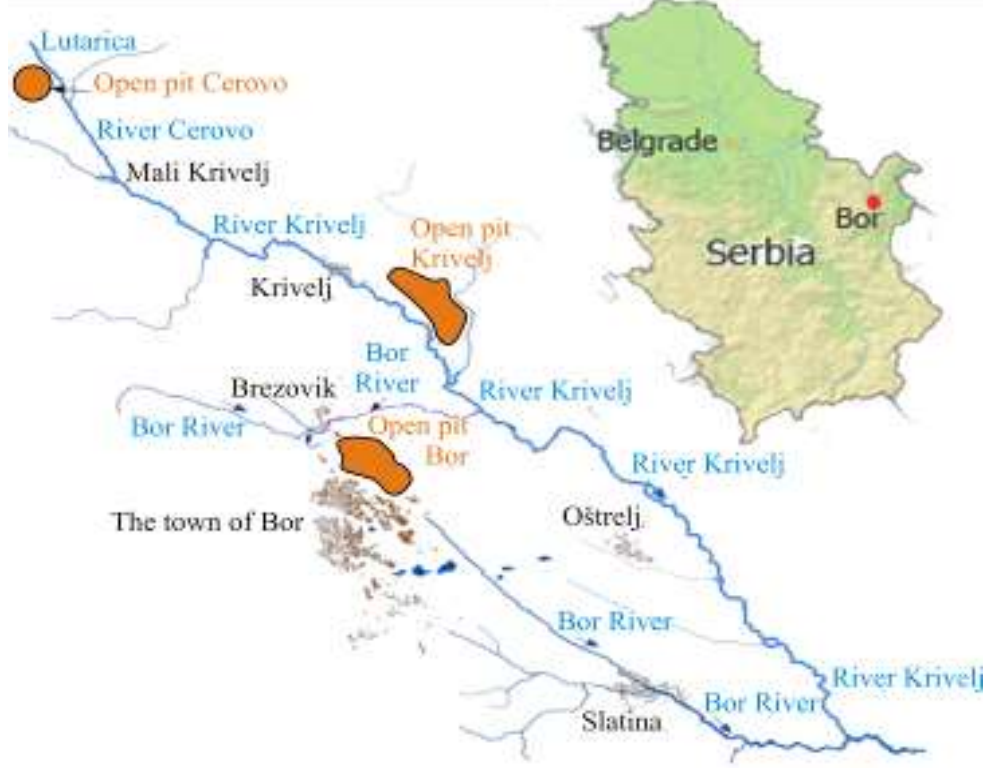

Figure 1. Location of the sampling sites of plant along the Krivelj River banks (Eastern Serbia) Slika 1. Lokacije uzorkovanja biljaka duž Kriveljske reke (Istočna Srbija) 


\section{MATERIALS AND METHODS}

\subsection{Description of the sampling sites}

Plant organs (root, shoot and leaves) of dandelion (Taraxacumspp.), nettle (Urtica dioica) and coltsfoot (Petasites officinalis), as well as the rhizospheric soil, were sampled on the banks of the Krivelj River in the Bor region (Eastern Serbia).
Plants and soil material were sampled at six sampling sites, which are shown in the Figure 1. The locations of the major pollution sources related to the copper production (open pits, flotation tailing ponds, overburden, landfilds) in the relation to the Krivelj River are given in the Figure 2.

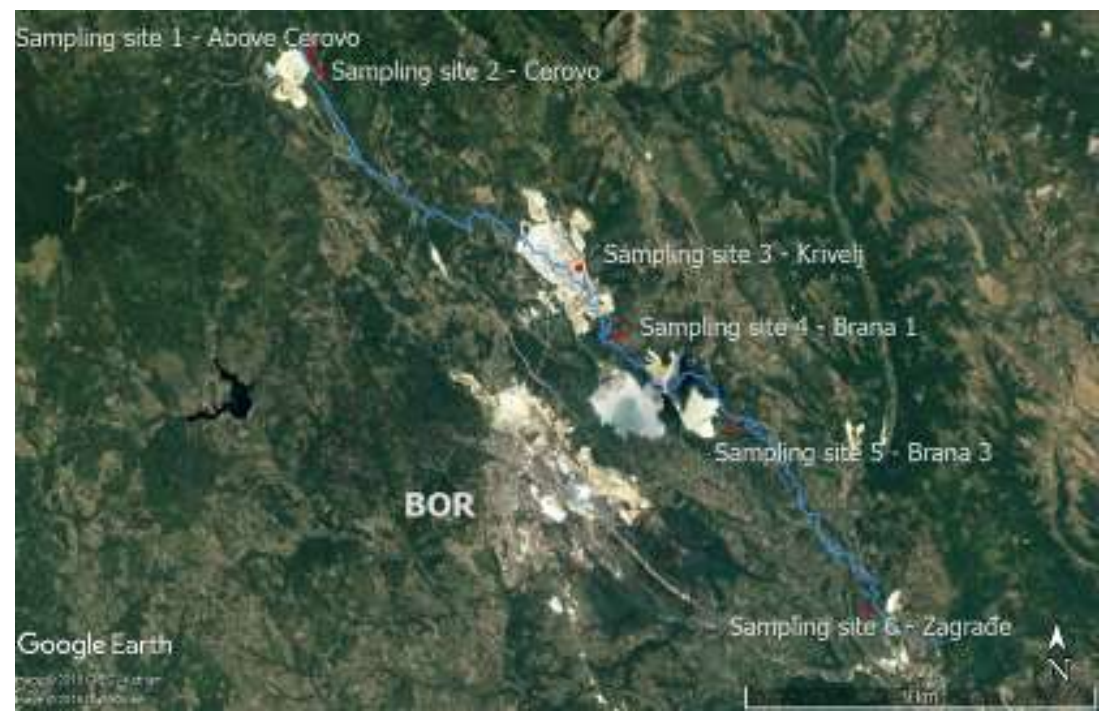

Figure 2. Aerial view of the sampling sites

Slika 2. Označena mesta uzorkovanja na mapi

The outskirts of the town of Bor are rich in copper; therefore the copper deposits located in this area are among the largest in Europe. This area is extremely polluted due exploiting of the copper sulphide ore in the two open pits (Cerovo and VelikiKrivelj) and one underground mine (the "Jama" in the town of Bor). Also, there is a huge Mining-metallurgical Complex Bor with two plants that perform mineral processing (flotations in Veliki Krivelj and Bor). The copper smelter, located on the northeastern border of the town, processes sulphide copper concentrate with the accompanying elements $\mathrm{Fe}, \mathrm{Pb}, \mathrm{As}, \mathrm{Cd}, \mathrm{Ni}, \mathrm{Zn}, \mathrm{Mn}$ and precious metals. The main pollution sources of the Krivelj River were: waste waters from the open pits of VelikiKrivelj and Bor surface mines which were pumped into the Krivelj River, drainage wastewaters from the overburden dumps of the VelikiKrivelj mine, wastewaters from the dams $1 \mathrm{~A}$ and $3 \mathrm{~A}$ of the flotation tailing ponds of the VelikiKrivelj mine (Figure 1). The average annual amount of metal(loid)s discharged through wastewaters into watercourses were: $501 \mathrm{t} \mathrm{year-1}^{-1}$ of $\mathrm{Cu}, 53 \mathrm{t}^{\text {year }^{-1}}$ of $\mathrm{Zn}, 1.8 \mathrm{t}_{\text {year }}{ }^{-1}$ of $\mathrm{Pb}, 0.4 \mathrm{t}_{\text {year }}{ }^{-1}$ of As, and $0.26 \mathrm{t} \mathrm{year}^{-1}$ of $\mathrm{Cd}$. Wastewaters, instilled into the Krivelj and Bor Rivers, via the Timok River, pollute the Danube Basin downstream toward the Black Sea $[27,28]$.

\subsection{Sampling of the plants and soil material and chemical analysis of samples}

Sampling was carried out in three terms during 2012: April (I term), May (II term) and June (III term), in order to analyse metal(loid) accumulation patterns in relation to time. The soil and plant samples were taken from the selected six sites, including the control site. From the each site, in each term, the plant material and rhizospheric soil of three to five plants of similar size and age were sampled. Subsamples were mixed into the one composite sample, representing dandelion roots, leaves and soil from the particular sampling site. In the laboratory, leaves and roots were thoroughly washed with tap water for a few minutes followed by distilled water. All the samples (plant and soil) were air dried to a constant weight at the room temperature. The samples were then ground to a fine powder and stored at the room temperature until the analysis.

All chemical analyses were performed in the Institute of Mining and Metallurgy Bor (Serbia). The soil samples were digested according to the EPA method 3052 [30] in a microwave oven by using nitric acid $\left(65 \% \mathrm{HNO}_{3}\right.$, J.T. Baker), hydrochloric acid (36.5-38.0\% HCl, J.T. Baker) and hydrofluoric acid (48\% HF, J.T. Baker) in the ratio 1:3:1 (v/v/v). Subsequently, boric acid $\left(4 \% \mathrm{H}_{3} \mathrm{BO}_{3}\right.$, 
J.T. Baker) was added to the samples to permit the complexation of fluoride to protect the quartz plasma torch. Afterwards samples were digested in the microwave. The leaves, shoot and root samples were digested according to the EPA method 3050B [29] in the microwave oven with a mixture of hydrogen-peroxide $\left(30 \% \mathrm{H}_{2} \mathrm{O}_{2}\right.$, Merck) and nitric acid $\left(65 \% \mathrm{HNO}_{3}\right.$, J.T. Baker) in the ratio $1: 5(\mathrm{v} / \mathrm{v})$. Analytical grade chemical reagents and ultra pure water were used in the chemical analyses.

Concentrations of $\mathrm{Cu}, \mathrm{Zn}, \mathrm{As}, \mathrm{Pb}$ and $\mathrm{Cd}$ were determined by the Inductively Coupled Plasma Atomic Emission Spectrometry (ICP-AES, model "SpectroCiros Vision"). The quality of the analytical data was checked by replicate analysis of the same samples. Soil $\mathrm{pH}$ was determined in suspension of soil with $1 \mathrm{~mol} \mathrm{dm}^{-3}$ solution of $\mathrm{KCl}(1: 5 \mathrm{v} / \mathrm{v})$, according to the ISO standard 10390:2005.

\subsection{Chemometric analysis}

The obtained results were expressed by means \pm standard deviation (SD) using the software package STATISTICA 10.0 (StatSoft Inc., Tulsa, OK, USA). Analysis of variance (ANOVA) and Tukey's HSD test were used to establish the differences in means between samples classified by four factors (sampling site, species type plant organ, and sampling time). The PCA was used to discover the possible correlations among measured parameters and to classify objects into groups.

First order polynomial (FOP) models in the following form were developed to relate responses $(Y)$ and two process variables $(X)$ (equation 1 ): Table 1. Concentration of elements in the soil

$$
Y=\beta_{0}+\sum_{i=1}^{4} \beta_{i} \cdot X_{i}
$$

where: $\beta_{0}$ and $\beta_{i}$ were constant regression coefficients; $Y$ : the content of toxic (As, Cd, $\mathrm{Hg}$ or $\mathrm{Pb}$ ) or essential elements (Cu or $\mathrm{Zn}$ ) in samples, while $X_{1}$ is the sampling site - Above Cerovo, Cerovo, Krivelj, Dam 1, Dam 3 and Zagrađe, $X_{2}$ is the cultivar - coltsfoot, dandelion and nettles, $X_{3}$ is the sample position/plants organs - soil, root, shoot and leaves; $X_{4}$ is the sample time - April, May or June. ANOVA was conducted to show the significant effects of independent variables to the responses, and to show which of responses were significantly affected by the varying variable combinations.

\section{RESULTS AND DISCUSSION}

\subsection{Elements concentration in soil}

The average values of elements concentration in soil collected at different sample stations, which varied to a great extent are presented in Table 1 . The higher As concentrations were found in Above Cerovo and Zagrađe sites. The concentrations of $\mathrm{Cd}$ and $\mathrm{Hg}$ were bellow LOD values. The highest $\mathrm{Pb}$ concentration was observed at Above Cerovo and Cerovo sites, while the increased concentration of $\mathrm{Cu}$ and $\mathrm{Zn}$ were found at Krivelj and Cerovo sites, respectively. The differences in $\mathrm{Pb}$ were found insignificant, while the detected concentrations of $\mathrm{As}, \mathrm{Cu}$ and $\mathrm{Zn}$ were notable.

Tabela 1. Koncentracije elemenata u zemljištu

\begin{tabular}{|l|c|c|c|c|c|c|}
\hline \multicolumn{1}{|c|}{ Site } & As & $\mathrm{Cd}$ & $\mathrm{Hg}$ & $\mathrm{Pb}$ & $\mathrm{Cu}$ & $\mathrm{Zn}$ \\
\hline Above Cerovo & $11.7 \pm 8.6^{\mathrm{a}}$ & $<0.5$ & $<1.0$ & $81.0 \pm 66.9^{\mathrm{a}}$ & $172.9 \pm 127.4^{\mathrm{a}}$ & $71.9 \pm 52.8^{\mathrm{a}}$ \\
\hline Cerovo & $86.4 \pm 56.8^{\mathrm{b}}$ & $<0.5$ & $<1.0$ & $76.7 \pm 16.2^{\mathrm{a}}$ & $359.2 \pm 48.9^{\mathrm{a}}$ & $168.2 \pm 22.8^{\mathrm{b}}$ \\
\hline Krivelj & $11.9 \pm 0.9^{\mathrm{a}}$ & $<0.5$ & $<1.0$ & $20.8 \pm 2.3^{\mathrm{a}}$ & $179.5 \pm 28.5^{\mathrm{a}}$ & $113.9 \pm 9.9^{\mathrm{ab}}$ \\
\hline Brana 1 & $19.8 \pm 4.2^{\mathrm{a}}$ & $<0.5$ & $<1.0$ & $22.9 \pm 1.1^{\mathrm{a}}$ & $1361.6 \pm 714.5^{\mathrm{b}}$ & $100.5 \pm 9.4^{\mathrm{a}}$ \\
\hline Brana 3 & $9.4 \pm 0.2^{\mathrm{a}}$ & $<0.5$ & $<1.0$ & $13.1 \pm 3.4^{\mathrm{a}}$ & $423.8 \pm 104.8^{\mathrm{a}}$ & $73.4 \pm 4.0^{\mathrm{a}}$ \\
\hline Zagrađe & $56.5 \pm 25.6^{\mathrm{ab}}$ & $<0.5$ & $<1.0$ & $41.0 \pm 11.8^{\mathrm{a}}$ & $493.1 \pm 98.5^{\mathrm{a}}$ & $117.4 \pm 15.2^{\mathrm{ab}}$ \\
\hline
\end{tabular}

a.b.c Different letters printed in superscript within the same column in the table show significantly different means of observed data (at $\mathrm{p}<0.05$ level).

The results presented in the Table 1 show an increase in the concentration of $\mathrm{Cu}, \mathrm{Zn}$ and $\mathrm{Pb}$ during entire monitoring period on all detection sites. This trend of increasing concentration levels can be linked to the fact that in April 2012, in this area, rainfall was several times heavier in comparison to May and June. Significant atmospheric water fluctuation contributed to the higher dissolution of various minerals present in the soil. However, in slightly acidic soils, the solubility of the $\mathrm{Cu}, \mathrm{Zn}$ and $\mathrm{Pb}$ in the water is small (Table 1 ); therefore the leaching of these elements did not take place. In opposition to previously mentioned metals, As has a higher solubility in water, which is usually illustrated with a decreasing trend of the average As concentration in samples of the soil [33]. Distribution patterns of the examined element's contents in soil are shown in Figure 3. 

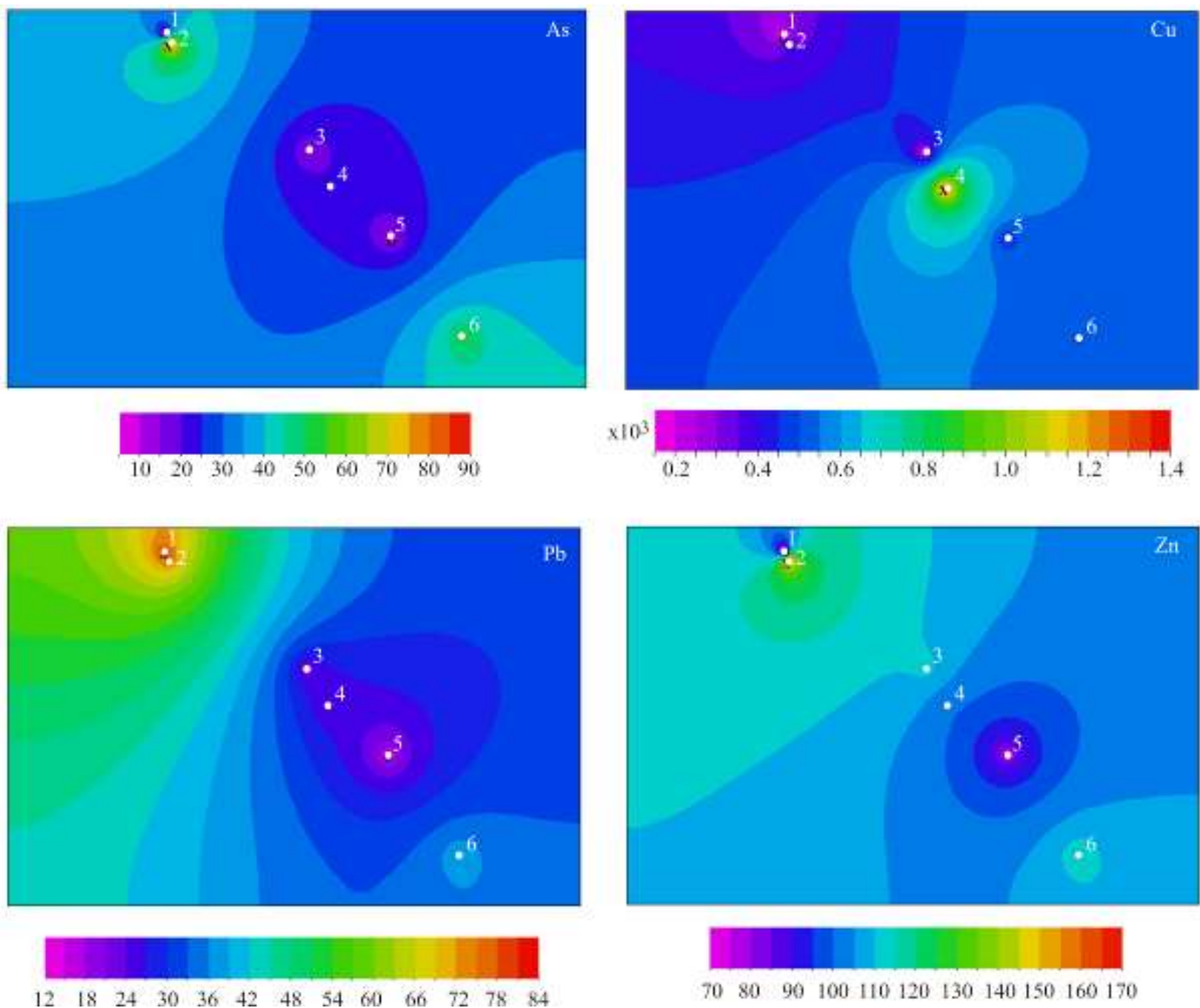

Figure 3. Distribution of elements (in $\mathrm{mg} / \mathrm{kg} \mathrm{dw}$ ) in soil

Slika 3. Distribucija elemenata (u mg/kg suve materije) u zemljištu

\subsection{Elements concentration in root}

The average values of elements concentration in root of different plants, collected at various sample stations, are presented in Table 2. The higher As concentrations were found in Zagrađe site. The concentrations of $\mathrm{Cd}$ were bellow LOD value, except for Cerovo, Krivelj and Brana 1 sites, while the concentration of $\mathrm{Hg}$ was bellow LOD value. The highest $\mathrm{Pb}$ concentration was observed at Krivelj site, while the increased concentration of $\mathrm{Cu}$ and $\mathrm{Zn}$ were detected at Krivelj and Cerovo sites. The differences in $\mathrm{Hg}$ were negligable, while the As, Cd, Cu and $\mathrm{Zn}$ concentrations were found significant among samples.

The values that are given in the Table 2 refer to the noticeable decreases in the $\mathrm{Cu}, \mathrm{Zn}$ and $\mathrm{Pb}$ concentrations detected in the roots of dandelion, nettle and coldsfoot. The concentrations were altered on a monthly basis. The only exception was the concentration of $\mathrm{Zn}$ in the roots of all investigated plants of whose decreasing trend no regularity could be ascribed. The decreasing tendency of $\mathrm{Cu}, \mathrm{Zn}$ and $\mathrm{Pb}$ concentrations in the plants is in the contrast to $\mathrm{Cu}, \mathrm{Zn}$ and $\mathrm{Pb}$ concentration changes that have been recorded on the samples of soil. This phenomenon is probably manifested due to the large abundance in the atmospheric water precipitation during the sampling period. Namely, the solubility of the $\mathrm{Cu}$, $\mathrm{Zn}$ and $\mathrm{Pb}$ was greater in the April, when the precipitation as on its highest level as well as the mobility of the monitored elements. Therefore, the quantity of detected elements in the plants was maximal during April, unlike the May-to-June period when the precipitation substantially diminished. 
Table 2. Concentration of elements in the root of different plants

Tabela 2. Koncentracija elemenata u korenu različitih biljaka

\begin{tabular}{|c|c|c|c|c|c|c|c|}
\hline Site & Plant & As & $\mathrm{Cd}$ & $\mathrm{Hg}$ & $\mathrm{Pb}$ & $\mathrm{Cu}$ & $\mathrm{Zn}$ \\
\hline \multirow{3}{*}{$\begin{array}{l}\text { Above } \\
\text { Cerovo }\end{array}$} & Dandelion & $3.0 \pm 0.0^{a}$ & $<0.5$ & $<1.0$ & $6.0 \pm 1.6^{a}$ & $89.9 \pm 30.4^{a}$ & 44. $6 \pm 3.0^{\mathrm{abc}}$ \\
\hline & Nettle & $3.9 \pm 0.7^{a}$ & $<0.5$ & $<1.0$ & $7.6 \pm 1.3^{a}$ & $87.4 \pm 33.4^{a}$ & $47.9 \pm 7.6^{\mathrm{abcd}}$ \\
\hline & Coldsfoot & $4.0 \pm 1.3^{a}$ & $<0.5$ & $<1.0$ & $3.4 \pm 1.7^{\mathrm{a}}$ & $95.4 \pm 12.2^{\mathrm{a}}$ & $54.0 \pm 1.3^{\mathrm{abcd}}$ \\
\hline \multirow{3}{*}{ Cerovo } & Dandelion & $3.6 \pm 1.1^{a}$ & $0.8 \pm 0.1^{\mathrm{ab}}$ & $<1.0$ & $6.1 \pm 5.4^{\mathrm{a}}$ & $129.9 \pm 94.6^{\mathrm{ab}}$ & $71.7 \pm 10.1^{\text {cde }}$ \\
\hline & Nettle & $5.5 \pm 0.7^{\mathrm{ab}}$ & $0.7 \pm 0.1^{\mathrm{ab}}$ & $<1.0$ & $11.7 \pm 5.3^{\mathrm{ab}}$ & $208.7 \pm 42.0^{\mathrm{ab}}$ & $67.7 \pm 4.0^{\mathrm{bcd}}$ \\
\hline & Coldsfoot & $6.5 \pm 1.2^{\mathrm{ab}}$ & $0.8 \pm 0.1^{\mathrm{ab}}$ & $<1.0$ & $22.8 \pm 10.1^{\mathrm{ab}}$ & $204.6 \pm 75.2^{\mathrm{ab}}$ & $102.7 \pm 11.3^{\mathrm{e}}$ \\
\hline \multirow{3}{*}{ Krivelj } & Dandelion & $9.0 \pm 5.9^{a b}$ & $0.9 \pm 0.5^{b}$ & $<1.0$ & $85.4 \pm 100.5^{b}$ & $375.1 \pm 317.7^{b}$ & $77.5 \pm 9.3^{\text {de }}$ \\
\hline & Nettle & 7. $1 \pm 0.3^{\mathrm{ab}}$ & $0.6 \pm 0.1^{\mathrm{ab}}$ & $<1.0$ & $22.4 \pm 9.1^{\mathrm{ab}}$ & $233.1 \pm 55.7^{\mathrm{ab}}$ & $67.4 \pm 20.7^{\text {bcd }}$ \\
\hline & Coldsfoot & $3.0 \pm 0.0^{a}$ & $<0.5$ & $<1.0$ & $12.5 \pm 10.4^{\mathrm{ab}}$ & $120.3 \pm 66.9^{a}$ & 42. $2 \pm 3.4^{\mathrm{abc}}$ \\
\hline \multirow{3}{*}{ Brana 1} & Dandelion & $4.5 \pm 1.3^{a b}$ & $0.5 \pm 0.0^{\mathrm{a}}$ & $<1.0$ & $11.5 \pm 9.2^{\mathrm{ab}}$ & $190.9 \pm 26.9^{\mathrm{ab}}$ & $49.8 \pm 1.7^{\mathrm{abcd}}$ \\
\hline & Nettle & $6.4 \pm 0.8^{\mathrm{ab}}$ & $<0.5$ & $<1.0$ & $15.6 \pm 8.2^{\mathrm{ab}}$ & $180.9 \pm 55.2^{\mathrm{ab}}$ & $40.8 \pm 10.6^{\mathrm{abc}}$ \\
\hline & Coldsfoot & $5.0 \pm 0.8^{\mathrm{ab}}$ & $<0.5$ & $<1.0$ & $12.7 \pm 8.8^{\mathrm{ab}}$ & $204.4 \pm 60.1^{\mathrm{ab}}$ & $42.0 \pm 3.1^{\mathrm{abc}}$ \\
\hline \multirow{3}{*}{ Brana 3} & Dandelion & $3.4 \pm 0.6^{a}$ & $<0.5$ & $<1.0$ & $2.3 \pm 0.4^{a}$ & $178.0 \pm 41.0^{\mathrm{ab}}$ & $36.4 \pm 4.7^{\mathrm{ab}}$ \\
\hline & Nettle & $3.0 \pm 0.0^{a}$ & $<0.5$ & $<1.0$ & $2.5 \pm 0.9^{a}$ & $129.3 \pm 22.9^{\mathrm{ab}}$ & $26.8 \pm 3.4^{a}$ \\
\hline & Coldsfoot & $3.8 \pm 0.8^{a}$ & $<0.5$ & $<1.0$ & $4.3 \pm 2.2^{\mathrm{a}}$ & $306.9 \pm 20.6^{\mathrm{ab}}$ & $35.6 \pm 6.0^{\mathrm{ab}}$ \\
\hline \multirow{3}{*}{ Zagrađe } & Dandelion & $7.1 \pm 3.5^{\mathrm{ab}}$ & $0.6 \pm 0.1^{\mathrm{ab}}$ & $<1.0$ & $6.6 \pm 4.2^{\mathrm{a}}$ & $216.2 \pm 65.7^{\mathrm{ab}}$ & $58.2 \pm 25.4^{\mathrm{abcd}}$ \\
\hline & Nettle & 10. $1 \pm 3.6^{b}$ & $0.7 \pm 0.1^{\mathrm{ab}}$ & $<1.0$ & $10.3 \pm 4.0^{\mathrm{a}}$ & $154.9 \pm 43.0^{\mathrm{ab}}$ & $69.5 \pm 18.6^{\text {cd }}$ \\
\hline & Coldsfoot & $5.9 \pm 0.5^{\mathrm{ab}}$ & $0.5 \pm 0.0^{\mathrm{ab}}$ & $<1.0$ & $7.3 \pm 4.0^{\mathrm{a}}$ & $144.2 \pm 11.4^{\mathrm{ab}}$ & $45.1 \pm 4.0^{\mathrm{abcd}}$ \\
\hline
\end{tabular}

a.b.c Different letters printed in superscript within the same column in the table show significantly different means of observed data (at $\mathrm{p}<0.05$ level).

\subsection{Elements concentration in the leaves}

The average values of elements concentration in leaves of different plants, collected at various sample stations, are presented in Table 3. The higher As concentrations were found in Zagrađe site. The concentrations of $\mathrm{Hg}$ and $\mathrm{Cd}$ were bellow LOD value. The highest As concentration was observed at Zagrađe site. The highest $\mathrm{Pb}$ concentration was registered at Krivelj site, while the increased concentration of $\mathrm{Cu}$ and $\mathrm{Zn}$ were found at Krivelj, Zagrađe and Cerovo sites. The differences in $\mathrm{Cd}$ and $\mathrm{Hg}$ were found insignificant, while the concentrations of $\mathrm{As}, \mathrm{Cu}$ and $\mathrm{Zn}$ were found significant among samples.

Table 3. Concentration of elements in leaves of different plant

Tabela 3. Koncentracija elemenata u lišću različitih biljaka

\begin{tabular}{|c|c|c|c|c|c|c|c|}
\hline Site & Plant & As & $\mathrm{Cd}$ & $\mathrm{Hg}$ & $\mathrm{Pb}$ & $\mathrm{Cu}$ & $\mathrm{Zn}$ \\
\hline \multirow{3}{*}{$\begin{array}{l}\text { Above } \\
\text { Cerovo }\end{array}$} & Dandelion & $3.0 \pm 0.0^{a}$ & $<0.5$ & $<1.0$ & $2.7 \pm 1.1^{a}$ & $42.9 \pm 23.1^{\mathrm{a}}$ & $28.8 \pm 4.6^{a}$ \\
\hline & Nettle & $4.6 \pm 2.4^{\mathrm{ab}}$ & $<0.5$ & $<1.0$ & $5.7 \pm 4.2^{\mathrm{a}}$ & $85.9 \pm 54.4^{\mathrm{abc}}$ & $36.0 \pm 15.4^{\mathrm{abc}}$ \\
\hline & Coldsfoot & $3.0 \pm 0.0^{\mathrm{a}}$ & $<0.5$ & $<1.0$ & $2.8 \pm 0.9^{a}$ & $56.3 \pm 8.0^{\mathrm{ab}}$ & $24.4 \pm 5.6^{a}$ \\
\hline \multirow{3}{*}{ Cerovo } & Dandelion & $3.5 \pm 0.9^{a}$ & $<0.5$ & $<1.0$ & $8.4 \pm 2.4^{a}$ & $133.6 \pm 49.6^{\mathrm{abcd}}$ & $90.3 \pm 19.0^{e}$ \\
\hline & Nettle & $5.3 \pm 2.6^{\mathrm{ab}}$ & $<0.5$ & $<1.0$ & $8.3 \pm 2.5^{a}$ & $127.6 \pm 23.5^{\mathrm{abcd}}$ & $60.8 \pm 27.9^{\text {bcde }}$ \\
\hline & Coldsfoot & $3.0 \pm 0.0^{a}$ & $<0.5$ & $<1.0$ & $6.0 \pm 2.2^{\mathrm{a}}$ & $93.0 \pm 8.6^{\mathrm{abcd}}$ & $59.7 \pm 14.8^{\mathrm{bcd}}$ \\
\hline \multirow{3}{*}{ Krivelj } & Dandelion & $3.9 \pm 1.5^{\mathrm{a}}$ & $<0.5$ & $<1.0$ & $17.8 \pm 14.6^{a}$ & $126.5 \pm 50.1^{\mathrm{abcd}}$ & $54.0 \pm 5.4^{\mathrm{abcd}}$ \\
\hline & Nettle & $3.9 \pm 1.5^{\mathrm{a}}$ & $<0.5$ & $<1.0$ & $17.3 \pm 20.9^{a}$ & $117.1 \pm 63.2^{\mathrm{abcd}}$ & $40.3 \pm 10.8^{a b c}$ \\
\hline & Coldsfoot & $4.0 \pm 1.7^{a}$ & $<0.5$ & $<1.0$ & $23.3 \pm 23.9^{a}$ & $180.3 \pm 40.9^{c d}$ & $37.0 \pm 16.7^{\mathrm{abc}}$ \\
\hline \multirow{3}{*}{ Brana 1} & Dandelion & $6.6 \pm 2.5^{\mathrm{ab}}$ & $<0.5$ & $<1.0$ & $12.8 \pm 6.2^{\mathrm{a}}$ & $164.5 \pm 9.9^{\text {cd }}$ & $83.3 \pm 18.5^{\mathrm{de}}$ \\
\hline & Nettle & $7.1 \pm 3.1^{\mathrm{ab}}$ & $<0.5$ & $<1.0$ & $10.0 \pm 1.0^{\mathrm{a}}$ & $168.1 \pm 77.2^{\mathrm{cd}}$ & $38.3 \pm 12.8^{a b c}$ \\
\hline & Coldsfoot & $5.4 \pm 1.8^{\mathrm{ab}}$ & $<0.5$ & $<1.0$ & $6.6 \pm 1.2^{\mathrm{a}}$ & $167.7 \pm 77.7^{\mathrm{cd}}$ & $52.1 \pm 5.0^{\mathrm{abc}}$ \\
\hline \multirow{3}{*}{ Brana 3} & Dandelion & $3.0 \pm 0.0^{\mathrm{a}}$ & $<0.5$ & $<1.0$ & $3.3 \pm 0.9^{a}$ & $192.5 \pm 78.0^{\mathrm{d}}$ & $45.7 \pm 2.8^{\mathrm{abc}}$ \\
\hline & Nettle & $3.4 \pm 0.5^{\mathrm{a}}$ & $<0.5$ & $<1.0$ & $3.4 \pm 1.3^{\mathrm{a}}$ & $171.6 \pm 16.3^{\mathrm{cd}}$ & $32.1 \pm 8.0^{\mathrm{ab}}$ \\
\hline & Coldsfoot & $3.0 \pm 0.1^{\mathrm{a}}$ & $<0.5$ & $<1.0$ & $2.2 \pm 0.3^{a}$ & $129.2 \pm 27.6^{\mathrm{abcd}}$ & $33.5 \pm 2.4^{\mathrm{abc}}$ \\
\hline \multirow{3}{*}{ Zagrađe } & Dandelion & $6.9 \pm 1.1^{\mathrm{ab}}$ & $<0.5$ & $<1.0$ & $7.8 \pm 2.8^{a}$ & $148.2 \pm 11.6^{\mathrm{bcd}}$ & $62.4 \pm 7.0^{\text {cde }}$ \\
\hline & Nettle & 8. $3 \pm 0.6^{b}$ & $<0.5$ & $<1.0$ & $7.2 \pm 1.4^{\mathrm{a}}$ & $148.5 \pm 14.4^{\mathrm{bcd}}$ & $60.4 \pm 16.6^{\text {bcde }}$ \\
\hline & Coldsfoot & $5.4 \pm 2.3^{\mathrm{ab}}$ & $<0.5$ & $<1.0$ & $4.9 \pm 1.3^{a}$ & $131.6 \pm 35.9^{\mathrm{abcd}}$ & $37.6 \pm 1.0^{\mathrm{abc}}$ \\
\hline
\end{tabular}

a.b.c Different letters printed in superscript within the same column in the table show significantly different means of observed data (at $\mathrm{p}<0.05$ level). 
The changes noticed in the concentrations of $\mathrm{Cu}, \mathrm{Zn}$ and $\mathrm{Pb}$ detected in the plant leaves were similar to those registers on the root. Namely, the $\mathrm{Cu}, \mathrm{Zn}$ and $\mathrm{Pb}$ concentrations followed the decreasing trend. The concentration of copper in the root of a plant was higher than the concentration detected in the leaf on all sites of the investigation. This observation confirms the fact that copper possesses a slight mobility, and therefore the $\mathrm{Cu}$ reserves in the roots of plants are higher [32].

\subsection{Elements concentration in shoot}

The average values of elements concentration in shoot of different plants, collected at various sample stations, are presented in Table 4. The higher As concentrations were found in Zagrađe site. The concentrations of $\mathrm{Hg}$ and $\mathrm{Cd}$ were bellow LOD value. The highest As concentration was observed at Zagrađe site. The highest $\mathrm{Pb}$ concentration was observed at Krivelj site, while the increased concentration of $\mathrm{Cu}$ and $\mathrm{Zn}$ were found at Krivelj, Zagrađe and Cerovo sites. The differences in $\mathrm{Cd}$ and $\mathrm{Hg}$ were found insignificant, while the concentrations of $\mathrm{As}, \mathrm{Cu}$ and $\mathrm{Zn}$ were found significant among samples.

Table 4. Concentration of elements in the shoot of different plants

Tabela 4. Koncentracija elemenata u stablu različitih biljaka

\begin{tabular}{|l|c|c|c|c|c|c|c|}
\hline \multicolumn{1}{|c|}{ Site } & Plant & $\mathrm{As}$ & $\mathrm{Cd}$ & $\mathrm{Hg}$ & $\mathrm{Pb}$ & $\mathrm{Cu}$ & $\mathrm{Zn}$ \\
\hline \multirow{2}{*}{$\begin{array}{l}\text { Above } \\
\text { Cerovo }\end{array}$} & Nettle & $3.0 \pm 0.0^{\mathrm{a}}$ & $<0.5$ & $<1.0$ & $2.6 \pm 1.1^{\mathrm{a}}$ & $62.6 \pm 15.3^{\mathrm{a}}$ & $32.1 \pm 8.3^{\mathrm{abc}}$ \\
\cline { 2 - 8 } Cerovo & Coldsfoot & $3.0 \pm 0.0^{\mathrm{a}}$ & $<0.5$ & $<1.0$ & $3.2 \pm 1.8^{\mathrm{a}}$ & $65.7 \pm 16.0^{\mathrm{a}}$ & $32.2 \pm 7.0^{\mathrm{abc}}$ \\
\cline { 2 - 8 } & Nettle & $3.2 \pm 0.3^{\mathrm{a}}$ & $<0.5$ & $<1.0$ & $5.6 \pm 1.2^{\mathrm{a}}$ & $121.8 \pm 33.6^{\mathrm{abc}}$ & $53.9 \pm 23.4^{\mathrm{cde}}$ \\
\cline { 2 - 8 } Krivelj & Coldsfoot & $3.7 \pm 1.2^{\mathrm{a}}$ & $<0.5$ & $<1.0$ & $5.9 \pm 1.1^{\mathrm{a}}$ & $180.0 \pm 25.6^{\mathrm{bc}}$ & $64.6 \pm 1.7^{\mathrm{de}}$ \\
\cline { 2 - 8 } & Nettle & $4.8 \pm 1.0^{\mathrm{ab}}$ & $<0.5$ & $<1.0$ & $32.5 \pm 25.3^{\mathrm{b}}$ & $145.1 \pm 35.4^{\mathrm{abc}}$ & $51.6 \pm 3.2^{\mathrm{bcd}}$ \\
\hline \multirow{2}{*}{ Brana 1 } & Coldsfoot & $3.4 \pm 0.8^{\mathrm{a}}$ & $<0.5$ & $<1.0$ & $12.7 \pm 16.0^{\mathrm{ab}}$ & $106.0 \pm 56.1^{\mathrm{abc}}$ & $29.0 \pm 10.8^{\mathrm{ab}}$ \\
\cline { 2 - 8 } & Nettle & $3.1 \pm 0.2^{\mathrm{a}}$ & $<0.5$ & $<1.0$ & $4.6 \pm 1.1^{\mathrm{a}}$ & $94.8 \pm 30.3^{\mathrm{abc}}$ & $27.6 \pm 12.5^{\mathrm{ab}}$ \\
\hline \multirow{2}{*}{ Brana 3 } & Coldsfoot & $3.0 \pm 0.0^{\mathrm{a}}$ & $<0.5$ & $<1.0$ & $10.9 \pm 5.7^{\mathrm{ab}}$ & $75.3 \pm 20.0^{\mathrm{ab}}$ & $43.8 \pm 0.5^{\mathrm{abcd}}$ \\
\cline { 2 - 8 } & Nettle & $3.0 \pm 0.0^{\mathrm{a}}$ & $<0.5$ & $<1.0$ & $2.0 \pm 0.0^{\mathrm{a}}$ & $107.1 \pm 60.2^{\mathrm{abc}}$ & $26.8 \pm 1.1^{\mathrm{a}}$ \\
\hline \multirow{2}{*}{ Zagrađe } & Coldsfoot & $3.0 \pm 0.0^{\mathrm{a}}$ & $<0.5$ & $<1.0$ & $2.0 \pm 0.0^{\mathrm{a}}$ & $109.5 \pm 8.6^{\mathrm{abc}}$ & $24.9 \pm 3.4^{\mathrm{a}}$ \\
\cline { 2 - 8 } & Nettle & $7.2 \pm 1.8^{\mathrm{b}}$ & $<0.5$ & $<1.0$ & $5.1 \pm 2.5^{\mathrm{a}}$ & $190.9 \pm 29.2^{\mathrm{c}}$ & $78.2 \pm 6.1^{\mathrm{e}}$ \\
\cline { 2 - 8 } & Coldsfoot & $4.7 \pm 1.7^{\mathrm{ab}}$ & $<0.5$ & $<1.0$ & $4.6 \pm 2.0^{\mathrm{a}}$ & $136.2 \pm 41.0^{\mathrm{abc}}$ & $45.7 \pm 7.7^{\mathrm{abcd}}$ \\
\hline
\end{tabular}

a.b.cDifferent letters printed in superscript within the same column in the table show significantly different means of observed data (at $\mathrm{p}<0.05$ level).

The concentrations of $\mathrm{Cu}, \mathrm{Zn}$ and $\mathrm{Pb}$ detected in the shoots of nettle and coldsfoot plants were similar to those registers on the root and on the leaf, i.e. the concentrations exhibited decreasing tendency.

The correlation between elements concentration detected in the soil and in various plant organs is presented in Table 5.

Table 5. Correlations between elements concentration in soil and various plant organs

Tabela 5. Korelacije između koncentracija elemenata u zemljištu i različitim biljnim organima

\begin{tabular}{|c|c|c|c|c|c|c|c|}
\hline & & As & Cd & Pb & Cu & Zn \\
\hline & \multicolumn{7}{|c|}{ Root } \\
\hline Soil & Nettle & 0.385 & $/$ & -0.190 & 0.118 & $0.737^{* *}$ \\
\hline & Dandelion & -0.052 & $/$ & -0.360 & -0.076 & $0.790^{* *}$ \\
\hline & Coldsfoot & $0.906^{*}$ & $/$ & 0.236 & 0.324 & $0.797^{* *}$ \\
\hline & Nettle & $0.896^{*}$ & $/$ & $0.825^{*}$ & 0.475 & $0.861^{*}$ \\
\hline Root & Coldsfoot & 0.567 & $0.998^{+}$ & 0.467 & 0.242 & $0.836^{*}$ \\
\hline & & \multicolumn{5}{|c|}{ Shoot } \\
\hline Shoot & Nettle & 0.585 & $/$ & $0.922^{+}$ & 0.277 & $0.856^{*}$ \\
\hline & Coldsfoot & 0.440 & $/$ & $0.819^{*}$ & -0.077 & $0.819^{*}$ \\
\hline
\end{tabular}

${ }^{+}$correlation is statistically significant at $p<0.01$ level; " correlation is statistically significant at $p<0.05$ level; ${ }^{* *}$ correlation is statistically significant at $p<0.10$ level. 
The correlation of As concentration between soil and coltsfoot root was found statistically significant at $p<0.05$ level, while the correlation of concentration of $\mathrm{Zn}$ in soil and root was found statistically significant at $p<0.10$ level, for all observed plants. The correlation of concentration of As, $\mathrm{Pb}$ and $\mathrm{Zn}$, between root and shoot in nettle is statistically significant at $p<0.05$. The correlation of concentration of $\mathrm{Zn}$, between root and shoot in coltsfoot is statistically significant at $p<0.05$, while the correlation of concentration of Cd between root and shoot in coltsfoot is statistically significant at $p<0.01$ level. The correlations of $Z n$ concentration between shot and leaf in nettle and coltsfoot are statistically significant at $\mathrm{p}<0.05$ level, while the correlations of $\mathrm{Pb}$ concentration in nettle leaves and coltsfoot are statistically significant at $p<0.01$ and $p<0.05$, respectively.

The negative effects of the environmental pollution, which is a result of the exploitation and processing of mineral raw materials in RTB Bor, primarily reflect in degradation of air, water and land due to the accumulation of the polluting elements. Deposited pollutants normally include toxic materials and ions of heavy metals originating from the same raw materials and toxic residual flotation reagents. The effect of toxic metals on the plants does not only depend on their concentration in the soil, but also the form in which the contaminant is located, of the soil $\mathrm{pH}$, redox potential and the presence of other ions in the soil, i.e. from the physico-chemical properties of soil as it was also confirmed by other authors [32,33].

The adoption of heavy metals by a plant, i.e. phyto-remediation, is primarily conducted through the root from the soil solution, and also partially through the aboveground organs from the atmosphere. The mechanism of the pollutant adoption depends on the binding and the solubility of the particles with aero sedimentation ability, which is deposited on the surfaces of plants' leaves. Namely, different plant species react differently to the presence of certain heavy metals in soil, water and air.

All three plants have proved to be good bioindicators for pollutants. The highest degree of pollutants accumulation was detected in the roots of all three plants. In the plants are mutually compared, the highest content of accumulated pollutants was observed in dandelion. Therefore, dandelion can be considered as the plant with the best exhibited pollutant accumulation ability. However, all three indicator species are suitable for planting and revitalization of the space around the mine and industrial plants, or where the soil is contaminated by heavy metals.

\subsection{The principal component analyses - PCA}

The algorithm of PCA can be found in standard chemometric material, [35,36], which justifies its application in the chemistry and eco-application of various plants. In summary, PCA decomposed the original matrix into several products of multiplication into loading (3 plant species type, 3 plant organs, 6 locations, 3 sampling times) and score (six toxic and essential elements concentration) matrices. Element concentration was expressed by six variables (columns of the input matrix) and experimental data of element concentration as mathematical-statistical cases (rows of the matrix).

The PCA allowed a considerable reduction in a number of variables and the detection of structure in the relationship between measuring parameters and different samples that give complementary information $[36,37]$. The full auto scaled data matrix was submitted to the PCA. The number of factors retained in the model for proper classification of experimental data, in original matrix into loading (different samples) and score (element content in samples) matrices were determined by application of Kaiser and Rice's rule [35]. This criterion retains only principal components with eigenvalues $>1$.

For visualizing the data trends and for the discriminating efficiency of the used descriptors a scatter plot of samples using the first two principal components (PCs) from PCA of the data matrix is obtained (Figure 4). As can be seen, there is a neat separation of the samples, according to the elements content. The quality results showed that first two principal components explained $71.06 \%$ of total variance, which could be considered as enough for presentation of the whole set of experimental data.

The contents of As (which contributed $22.1 \%$, of the total variance, calculated based on the correlation), $\mathrm{Pb}$ (25.1\%), $\mathrm{Cu}(16.2 \%)$ and $\mathrm{Zn}$ $(29.2 \%)$ were the most negatively influential factors for the first principal component evaluation. The influence of the Cd content in samples showed the strongest negative influence on the second principal component calculation $(71.8 \%$ of the total variance). The influence of different parameters that describes the observed samples could be evaluated from the scatter plot, Figure 4, in which the samples with higher element concentrations are located at the left side of the graphic. It is obvious that the samples of soil had the highest element content, while the root samples of all three cultivars had the highest element concentration of all plant organs. 


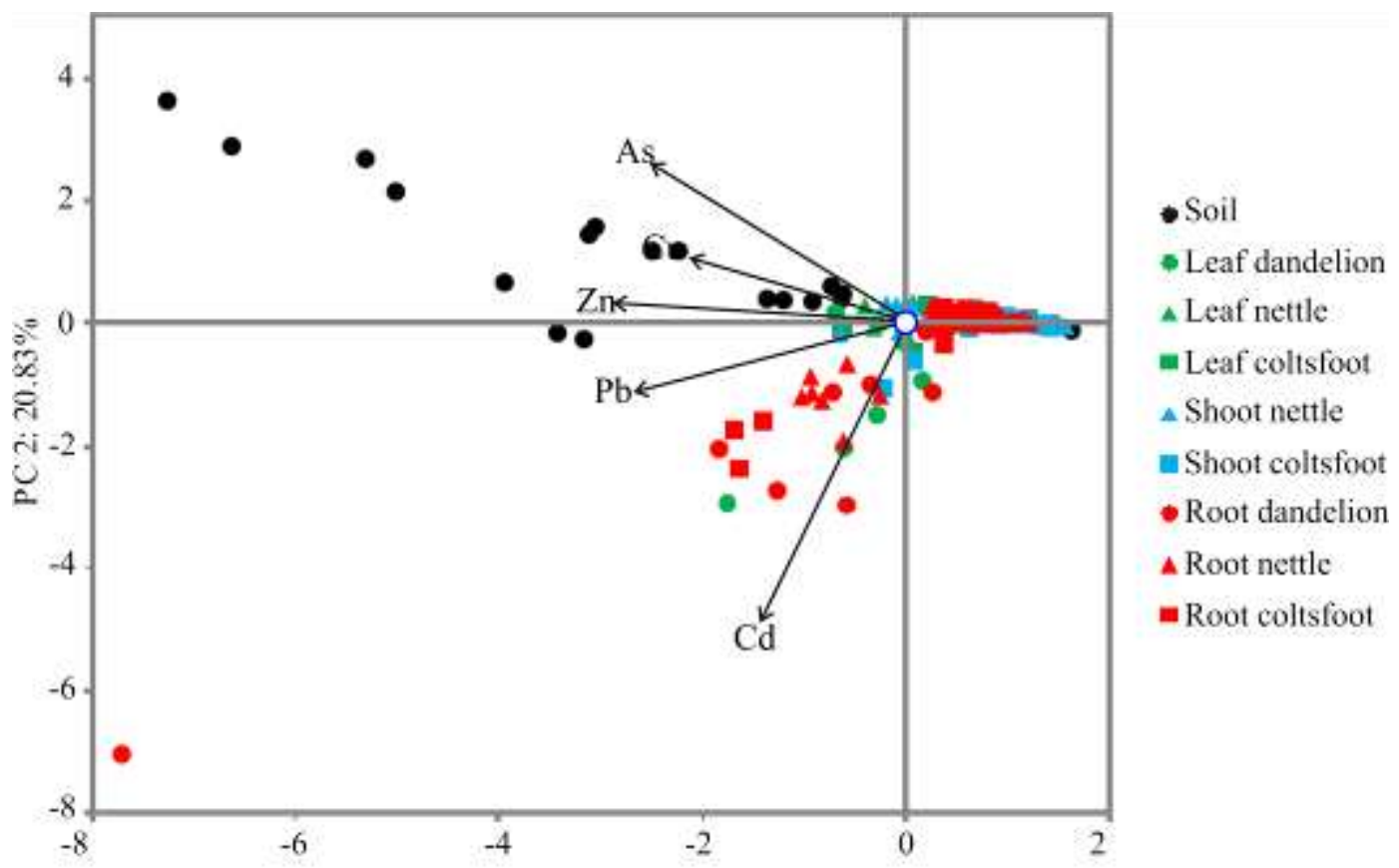

PC 1: $50.22 \%$

Figure 4. Biplot graphic of elements content in different plants and their organs

Slika 4. Biplot grafik sadržaja elemenata u različitim biljkama i njihovim organima

The PCA diagram illustrated in Figure 4, highlighted that all three investigated plants, i.e. dandelion, nettle and coltsfoot, were relatively good bioindicators of $\mathrm{As}, \mathrm{Cu}, \mathrm{Pb}$ and $\mathrm{Zn}$ (especially coldsfoot). The statistically significant correlation in case of $\mathrm{Hg}$ and $\mathrm{Cd}$ absorption was not determined, due to the fact that the concentrations of $\mathrm{Cd}$ in the soil and in the plants were below the detection limit.

ANOVA analysis (Table 6) revealed statistical significance of the sample type (i.e. soil and/or different organs of a plant) regarding absorbing ability of investigated toxic elements - As, $\mathrm{Cd}, \mathrm{Pb}$, $\mathrm{Cu}$, and $\mathrm{Zn}$.

\section{Table 6. ANOVA table of element content}

Tabela 6. ANOVA tabela sadržaja elemenata

\begin{tabular}{|l|c|c|c|c|c|c|}
\hline & df & As & $\mathrm{Cd}$ & $\mathrm{Pb}$ & $\mathrm{Cu}$ & $\mathrm{Zn}$ \\
\hline Sampling site & 1 & 65 & 0.03 & $1641^{* *}$ & $208622^{*}$ & 262 \\
\hline Plant & 1 & $3155^{+}$ & $0.12^{+}$ & $8468^{+}$ & $695180^{+}$ & $28379^{+}$ \\
\hline Organ & 1 & $1363^{+}$ & $0.25^{+}$ & 173 & 68032 & 1524 \\
\hline Time & 1 & 358 & 0.02 & 811 & 14814 & 1289 \\
\hline Error & 157 & 28395 & 1.81 & 74978 & 5595592 & 96680 \\
\hline
\end{tabular}

* Statistically significant at $p<0.001$ level, SoS - sum of squares, dF - degrees of freedom

ANOVA analysis (Table 6 ) revealed that the linear term of plant type in the first order polynomial model was found to be the most influential on As, $\mathrm{Pb}, \mathrm{Cu}$ and $\mathrm{Zn}$ content calculations (statistically significant at $p<0.01$ level. The linear term of plant organ was also influential for As concentration, $\mathrm{p}<0.01$ level. The calculation of $\mathrm{Cd}$ content is influenced by organ type and plant type, statistically significant at $\mathrm{p}<0.01$ level.

\section{CONCLUSIONS}

On the basis of this research, it can be concluded that the observed plants, like nettle, dandelion and coltsfoot, can be studied as bioindicators, on the basis of biological monitoring of pollution of land in industrial systems. It is shown that dandelion and nettle are bioindicators for As, $\mathrm{Cu}, \mathrm{Pb}$ and $\mathrm{Zn}$. Coltsfoot shows bioindicator capacity for almost all tested elements, except in the case of the maximum observed As concentration in the plant's leaves. In this case, on the basis of such distribution of this element coltsfoot can be considered as bioaccumulator of As.

The PCA illustrated that the investigated plants (dandelion, nettle and coltsfoot) were relatively good bioindicators of $\mathrm{As}, \mathrm{Cu}, \mathrm{Pb}$ and $\mathrm{Zn}$. The statistically significant correlation in case of $\mathrm{Hg}$ and $\mathrm{Cd}$ absorption was not determined, due to the fact that the concentrations of $\mathrm{Cd}$ in the soil and in the plants were below the detection limit.

Preliminary consideration is based on the fact that the wealth and diversity of vegetation are proportional to the nature and intensity of 
anthropogenic impacts in industrial ecosystems. Awareness of the ecological conditions of investigated species and biosystems, as well as the mechanisms of their adaptation to the conditions of toxic stress (which generally govern the urban biota), is imperative to modern ecological researches, which should provide the answers to many questions in the ecology.

\section{Acknowledgements}

This investigation was supported by Serbian Ministry of Education, Science and Technological Development.

\section{REFERENCES}

[1] Z. Huarong, X. Beicheng, F. Chen, Z.Peng, S.Shili (2012) Human health risk from soil heavy metal contamination under different land uses near Dabaoshan Mine, Southern China Science of the Total Environment, 417-418, 45-54.

[2] J.Wang, C.Chen (2009) Biosorbents for heavy metals removal and their future, Biotechnology Advances, 27, 195-226.

[3] A.Fernàndez, M.Ternero, F.Barragán, J.Jiménez (2000) An approach to characterization of sources of urban airborne particles through heavy metal speciation, Chemosphere- Global Change Science, 300, 123-136.

[4] G.Bonanno, R.Giudice (2010) Heavy metal bioaccumulation by the organs of Phragmites australis (common reed) and their potential use as contamination indicators, Ecological Indicators, 10, 639-645.

[5] Ö.Özden, T.Dögeroglu, S.Kara (2008) Assessment of ambient air quality in Eskisehir, Turkey, Environment International, 34, 678-687

[6] S.Yadav, V.Rajamani (2006) Air quality and trace metal chemistry of different size fractions of aerosols in NNW India-implications for source diversity, Atmospheric Environment, 40, 698-712.

[7] J.Y.Shparyk, V.I.Parpan (2004) Heavy metal pollution and forest health in the Carpathians, Environmental Pollution, 130, 55-63.

[8] M.Rivera, H.Zechmeister, M.Medina-Ramón, H. Basagaña, M. Foraster, L. Bouso, T. Moreno, P. Solanas, R. Ramos, G. Köllensperger, A. Deltell, D. Vizcaya, N. Künzli (2011) Monitoring of heavy metal concentrations in home outdoor air using moss bags, Environmental Pollution, 159, 954-962

[9] M.Antonijevic, M.Dimitrijevic, S.Milic, M.Njukic (2012) Metal concentrations in the soils and native plants surrounding the old flotation tailings pond of the Copper Mining and Smelting Complex Bor (Serbia), J.Envirion Monit.,14, 866-876.

[10] Ch.Eng, J.Paw, F.Guarin (1989) The environmental impact of aquaculture and the effects of pollution on coastal aquaculture development in Southeast Asia, Marine Pollution Bulletin, 20, 335-343.
[11] WHO (World Health Organization), Air Quality Guidelines for Europe, 2nd ed. WHO Regional Publications, Regional Office for Europe, Copenhagen, Denmark, 2001.

[12] G.Kaya, M.Yaman (2012) Determination of trace metals in plant leaves as biomonitor of pollution extent by a sensitive stat-aas method, Instrumentation Science \& Technology, 40, 61-74.

[13] G.Bullinger-Weber, C.Guenat, C.Salomé, J.Gobat, R. Claire Le Bayon (2012) Impact of flood deposits on earthworm communities in alder forests from a subalpine floodplain (Kandersteg, Switzerland), European Journal of Soil Biology, 49, 5-11.

[14] A. Baker, R. Brooks (1989) Terrestrial higher plants which hyper accumulate metallic elements - Review of their distribution, ecology and phytochemistry, Biorecovery, 1, 81-126.

[15] Y.Wen, J.He, X. Liu, J. Li, Y.Zhao (2012) Linear and non-linear relationships between bioconcentration and hydrophobicity: Theoretical consideration, Environmental Toxicology and Pharmacology, 34(2), 200-208.

[16] O.Stolyar, N.Loumbourdis, H.Falfushinska, D. Romanchuk (2008) Comparison of Metal Bioavailability in Frogs from Urban and Rural Sites of Western Ukraine, Archives of Environmental Contamination and Toxicology, 57, 107-113.

[17] B. Graupe, M. Anke, A. Rother (1960) Distribution of minerals and trace elements in different field plants, Jahrbuch der Arbeitsgemeinschaft Futterungsberatung, 3, 357-372.

[18] A.Kabata-Pendias, H.Pendias (2001) Trace elements in soils and plants. CRC Press LLC, Boca Raton.

[19] E.Królak (2003) Accumulation of $\mathrm{Zn}, \mathrm{Cu}, \mathrm{Pb}$ and $\mathrm{Cd}$ by Dandelion (Taraxacum officinale Web.) in Environments with Various Degrees of Metallic Contamination, Polish Journal of Environmental Studies, 6, 713-721.

[20] T.Motowicka-Terelak, H.Terelak (1997) Dandelion (Taraxacum officinale) as an indicator of sulphur contamination of Poland, $s$ agricultural environment,. W: Obieg pierwiastków w przyrodzie. Materiały z II Miedzynarodowej Konferencji, Warszawa 27-29 X. Instytut Ochrony Srodowiska, p.208-212.

[21] M.Malawska, B.Wiłkomirski (2001) An Analysis of Soil and Plant (Taraxacum officinale) Contamination with Heavy Metals and Policyclic Aromatic Hydrocarbons (PAHs) in the Area of the Railway Junction lława Główna, Poland., Water, Air,Soil Pollut, 127, 339-345.

[22] R.Carrillo, C.González (2006) Metal accumulation in wild plants surrounding mining wastes., Environ. Pollut., 144, 84-92.

[23] P. Chang, Y. Kim, W. Kim (2005) Concentrations of arsenic and heavy metals in vegetation at two abandoned mine tailings in South Korea, Environ. Geochem. Hlth, 27, 109-119.

[24] N.Haque, V.J.R.Peralta, G.L.Jones, T.E.Gill, T.J.L.Gardea (2008) Screening the phytoremediation potential of desert broom 2 
(Baccharis sarothroides Gray) growing on mine tailings in Arizona, USA., Environ. Pollut, 153, 362368.

[25] M.Gaweda, E.Capecka (2001) The content of some metals in stinging netlle (Urtica dioica L.) plants from natural sites in Malopolska.,Herba Pol., 47, 149-156.

[26] H. Zavvar Mousavi, S. Seyedi (2010) Nettle ash as a low cost adsorbent for the removal of nickel and cadmium from wastewater, International Journal of Environment Science and Technology., 8, 195-202.

[27] S.Sharma (1996) Applied Multivariate Techniques, Wiley, ISBN: 978-0-471-31064-8

[28] SM.Serbula, TS.Kalinovic, AA.llic, JV. Kalinovic, MM. Steharnik (2013) Assessment of airborne heavy metal pollution using Pinus spp. and Tilia spp., Aerosol Air Qual Res.,13, 563-573.

[29] S.M.Šerbula, M.M. Antonijevic, N.M. Miloševic, S.M. Milic, A.A. Ilic (2010) Concentrations of particulate matter and arsenic in Bor (Serbia); Journal of Hazardous Materials., 181, 43-51.

[30] EPA: hero.epa.gov/index.cfm/reference/download/ reference_id/755533
[31] F.Sun, D.Wen, Y.Kuang, J.Li, W.Zuo (2010) Concentrations of heavy metals and polycyclic aromatic hydrocarbons in needles of Masson pine (Pinus massoniana L.) growing nearby different industrial sources, Journal of Environmental Sciences., 22(7), 1006-1013.

[32] D.Gjorgieva, T.Kadifkova-Panovska, K.Baceva, T. Stafilov (2011) Assessment of Heavy Metal Pollution in Republic of Macedonia Using a Plant Assay, Arch Environ Contam Toxicol, 60, 233-240.

[33] R.Yu, G.Hu, L.Wang (2010) Speciation and ecological risk of heavy metals in intertidal sediments of Quanzhou Bay, China, Environ. Monit. Assess., 163, 241- 252.

[34] R.Flouty, G.Estephane (2012) Bioaccumulation and biosorption of copper and lead by a unicellular algae Chlamydomonas reinhardtii in single and binary metal systems: A comparative study, Journal of environmental managemen, 111, 106-114.

[35] HF. Kaiser and J. Rice (1974) Little Jiffy, mark IV. Educ Psychol Meas, 34, 111-117.

[36] M.Otto (1999) Chemometrics Statistics and Computer Application in Analytical Chemistry. Wiley-VCH, Weinheim, Germany.

\title{
IZVOD \\ BIOMETRIJSKE TEHNIKE ZA OCENU STEPENA USVAJANJA TOKSIČNIH I ESENCIJALNIH ELEMENATA
}

\begin{abstract}
Fokus ove studije je na biometrijsku klasifikaciju biljaka, biljnih organa, lokaliteta i vremena uzorkovanja, u smislu praćenja stepena usvajanja toksičanih ( $\mathrm{As}, \mathrm{Cd}, \mathrm{Hg}$ i $\mathrm{Pb}$ ) i esencijalnih elemenata (Cu i Zn), i mogućnost primene u fito-remedijaciji. Stepen usvajanja elemenata zavisi od biljne vrste $i$ njenih morfoloških $i$ fizioloških osobina. Usvajanje toksičnih i esencijalnih elemenata u ovom radu je praćeno kod tri vrste biljaka (podbel, maslačak i kopriva). Uzorkovanje biljaka $i$ zemljišta je vršeno u priobalnom regionu Kriveljske reke, Srbija. Analiza glavnih komponenti $i$ analiza varijanse su korišćene za procenu efekasnosti usvajanja toksičnih $i$ esencijalnih elemenata kod pomenutih biljnih vrsta, biljnih organa (korena, stabla i lišća), lokaliteta i vremena uzorkovanja (april, maj, jun). Dobijeni rezultati su pokazali da je razlika u usvajanju toksičnih $i$ esencijalnih elemenata najviše zavisi od sorte i tipova biljnih organa. Biometrijske tehnike pružaju mogućnost za bolje razumevanje ponašanja biljaka i dobijanja mnogo korisnih informacija iz izvornih podataka.
\end{abstract}

Ključne reči: podbel, maslačak, kopriva, toksični elementi, esencijalni elementi, biometrijski monitoring.

Naučni rad

Rad primljen: 12.09.2017.

Rad prihvaćen: 06.11.2017.

Rad je dostupan na sajtu: www.idk.org.rs/casopis

(C) 2018 Authors. Published by Engineering Society for Corrosion. This article is an open access article distributed under the terms and conditions of the Creative Commons Attribution 4.0 International license (https://creativecommons.org/licenses/by/4.0/) 